\title{
Proteomic characterization and bio-informatic analysis of differentially expressed $E$. coli Nissle 1917 proteins with response to cocoti wine stress
}

\author{
Chandrasekhar Kathera $^{1,2}$ - Esther Lebonah Dulla ${ }^{2}$ Venkata Prasad Chinahadri ${ }^{2}$. \\ Thanu Sree Mallakuntla Ramesh ${ }^{2} \cdot$ Sreedevi Basavaraju $^{2} \cdot$ Pramodakumari Jasti $^{2}$
}

Received: 3 December 2016/ Accepted: 21 March 2017/Published online: 8 June 2017

(c) Springer-Verlag Berlin Heidelberg 2017

\begin{abstract}
The present study emphases the comparative proteomic analysis of Escherichia coli Nissle 1917 under cocoti palm wine stress and identified differentially expressed proteins. Protein samples were analyzed by 2-D, MALDI-TOF combined with MS access. In 2-D electrophoresis, eight differentially expressed proteins were identified: five up-regulated, two down-regulated and one newly expressed protein. Protein spots were digested with trypsin for MALDI-TOF-MS analysis; protein sequences were obtained from MASCOT search. Sequences were aligned with template using Swiss Model server. Phyre-2 was used to predict homology modeling, RasMol was used to analyze the modeling structures, PSVS server was utilized to validate the protein structure by Ramachandran's plot analysis, physical and chemical properties were analyzed using ProtParam server, Phylogenetic tree was constructed by Mega4. UniProt search helps to find protein functional information of differentially expressed proteins, involved in catalytic activities, regulation mechanisms, DNA damage stimulus, anti-termination and termination process, protein binding, electron transport mechanism, and cell signaling process functions. A detailed exploration of the proteins under cocoti palm wine stress have provided the composition, structure and functions of the expressed proteins for further investigation.
\end{abstract}

Pramodakumari Jasti

pramodakumarij@gmail.com

1 Jiangsu Key Laboratory for Molecular and Medical Biotechnology, College of Life Sciences, Nanjing Normal University, 1 Wenyuan Road, Nanjing 210023, China

2 Department of Microbiology, Sri Venkateswara University, Tirupati 517502, A.P., India
Keywords Protein · 2-D analysis · MALDI-TOF/MS . Phylogenetic tree $\cdot$ ProtParam

\section{Introduction}

Probiotic microorganisms provide a healthy environment in the gut region and prevent from gastrointestinal disorders (Foxx-Orenstein and Chey 2012; Ringel et al. 2012). Generally, most of the probiotic bacteria are gram-positive, but in the current study, we have used gram-negative probiotic bacteria, E. coli Nissle 1917 (Nissle 1918). The gastrointestinal strain E. coli Nissle 1917 plays a vital role in remission of Bowel syndrome disease, ulcerative colitis and diarrhea (Henker et al. 2007). E. coli Nissle 1917 is used as a probiotic to treat gastrointestinal disorders, because of its semi rough lipopolysaccharides, the absence of protein toxins and the iron uptake system (Grozdanov et al. 2004). Consumption of alcohol can support small intestinal bacterial overgrowth (SIBO) which may induce structural changes of the gastrointestinal tract, and intestinal disorders (Gabbard et al. 2014). Palm wine is a local drink in rural areas, which contains some percentage of alcohol and it undergoes longer fermentation to yield a stronger one, which also acts as a natural medium for pathogenic microbial flora including acidophilic bacteria. When people consumed this palm wine, it influence on microbiota of the gastrointestinal tract (Eluwa et al. 2008).

$E$. coli can show different changes and make adjustments on a molecular level in growth period under stress conditions (Nystrom 2004). Many studies have reported on the bacterial proteomic changes in response to various stress conditions, but this work is a comprehensive proteomic approach for better understanding of the expressed 
proteins structure and mechanism in stress conditions of E. coli Nissle 1917 treated with cocoti wine (Soares et al. 2013). Proteomics are widely used for characterization and identification of proteins with MS-based techniques (MALDI-TOF/LC-MS) and bio-informatic tools (Krishnamurthy et al. 2000; Dworzanski et al. 2006). Proteomic studies can focus on looking deeply into the new modifications of proteins; it gives complete information about stress response (Agrawal et al. 2005). In last decade, MSbased technology developed into a high-sensitivity access for quantitative scrutiny of protein sample. The connectedness of 2-D gel electrophoresis, MS-based techniques and bio-informatic tools encourages microbial proteomic research widely. Identification and characterization of proteins in a cell are the most important strategies to assess molecular level mechanisms (Schmidt et al. 2014). The aim of this study was to provide a basic overview of palm wine influence on gastrointestinal probiotic microbes, and to perform MALDI-TOF MS/MS and bio-informatics for identification, characterization and understanding of their functions of expressed proteins.

\section{Materials and methods}

\section{Materials and chemicals reagents}

The Palm wine sample was collected from the Tirupati rural area, A.P, INDIA. Probiotic Escherichia coli Nissle 1917 was obtained from Ardeypharm GmbH, Germany. Nutrient Broth, Sodium dodecyl sulfate (SDS) and other chemicals were purchased from Brass Scientifics Tirupati. BCA Protein Assay Kit was purchased from Thermo Scientific. Inc. Protein isolated Kit and 2-D cleanup kit were purchased from Bio-Rad, 2-D gel electrophoresis and MALDI-TOF facility was provided by Hyderabad Central University (HCU), Telangana State, INDIA.

\section{Sample collection}

As stated earlier, the palm wine sample was collected from the Tirupati rural area AP, India and filtered using Millipore nitrocellulose membrane filters $(0.02 \mu)$ to separate the microorganisms present in palm wine.

\section{Culture collection and conditions}

E. coli Nissle 1917 was obtained from the culture collection center of Ardeypharm GmbH, Herdecke, Germany. The bacterial culture of $E$. coli Nissle 1917 was grown in $50 \mathrm{ml}$ Luria broth supplemented with $50 \mathrm{mg} / \mathrm{L}$ Ampicillin at $37{ }^{\circ} \mathrm{C}$, overnight with shaking until the OD reached 0.5 (McFarland standard). Palm wine was added based on MIC
Table 1 Growth values of control and palm wine-treated E. coli Nissle 1917

\begin{tabular}{lll}
\hline $\begin{array}{l}\text { Time intervals } \\
\text { (min) }\end{array}$ & O.D Values & \\
\cline { 2 - 3 } & E. coli Nissle 1917 (control) & $\begin{array}{l}\text { E. coli Nissle 1917 } \\
\text { (Palm wine treated) }\end{array}$ \\
\hline 30 & 0.03 & 0.02 \\
60 & 0.05 & 0.02 \\
90 & 0.09 & 0.06 \\
120 & 0.16 & 0.11 \\
150 & 0.21 & 0.12 \\
180 & 0.26 & 0.12 \\
210 & 0.28 & 0.12 \\
240 & 0.28 & 0.12 \\
\hline
\end{tabular}

concentration, and the optical density values were recorded at $670 \mathrm{~nm}$ (John 2005) and the values are shown in Table 1 and Fig. 1.

\section{Protein extraction}

Cultures were grown until mid-exponential phase and proteins were isolated from control and palm wine-treated probiotic E. coli Nissle 1917. To achieve this, culture media were centrifuged with the culture, and the pellet was washed with phosphate buffer to remove unwanted debris. Then the pellet was re-suspended and sonicated to break at $30 \mathrm{~s}$ with the pulse of $1 \mathrm{~s}$ at $40 \%$ amplitude, and subsequently centrifuged the contents to collect the supernatant. Proteins were extracted from the supernatant (crude) by the method of the Trizol protein extraction method. Protein sample was kept at $-20{ }^{\circ} \mathrm{C}$ for further analysis (Panga et al. 2013).

\section{2-D gel electrophoresis and staining}

Protein samples were purified with the 2-D cleanup kit, because the protein samples contain salts and detergent particles. $24 \mathrm{~cm}$ long, 4-7 pH gradient strips were used to separate proteins based on molecular weight and charge. Samples were combined with solubilizing buffer loaded into the strip holder, placed the strips and covered the strips using covering gel, allowed for Isoelectric Focusing. After completion of Isoelectric Focusing step, the strips were treated for rehydration with equilibrium buffer Iodoacetamide (IAA). Later placed the strip into the casting plate to set the instrument with loaded running buffer to allow second dimension. After 2-D gel electrophoresis, gel stained with colloidal coomassie brilliant blue stain was used (www.gelifesciences.com) (Rabilloud and Lelong 2011). 
Fig. 1 Growth values of control and palm wine-treated E. coli Nissle 1917

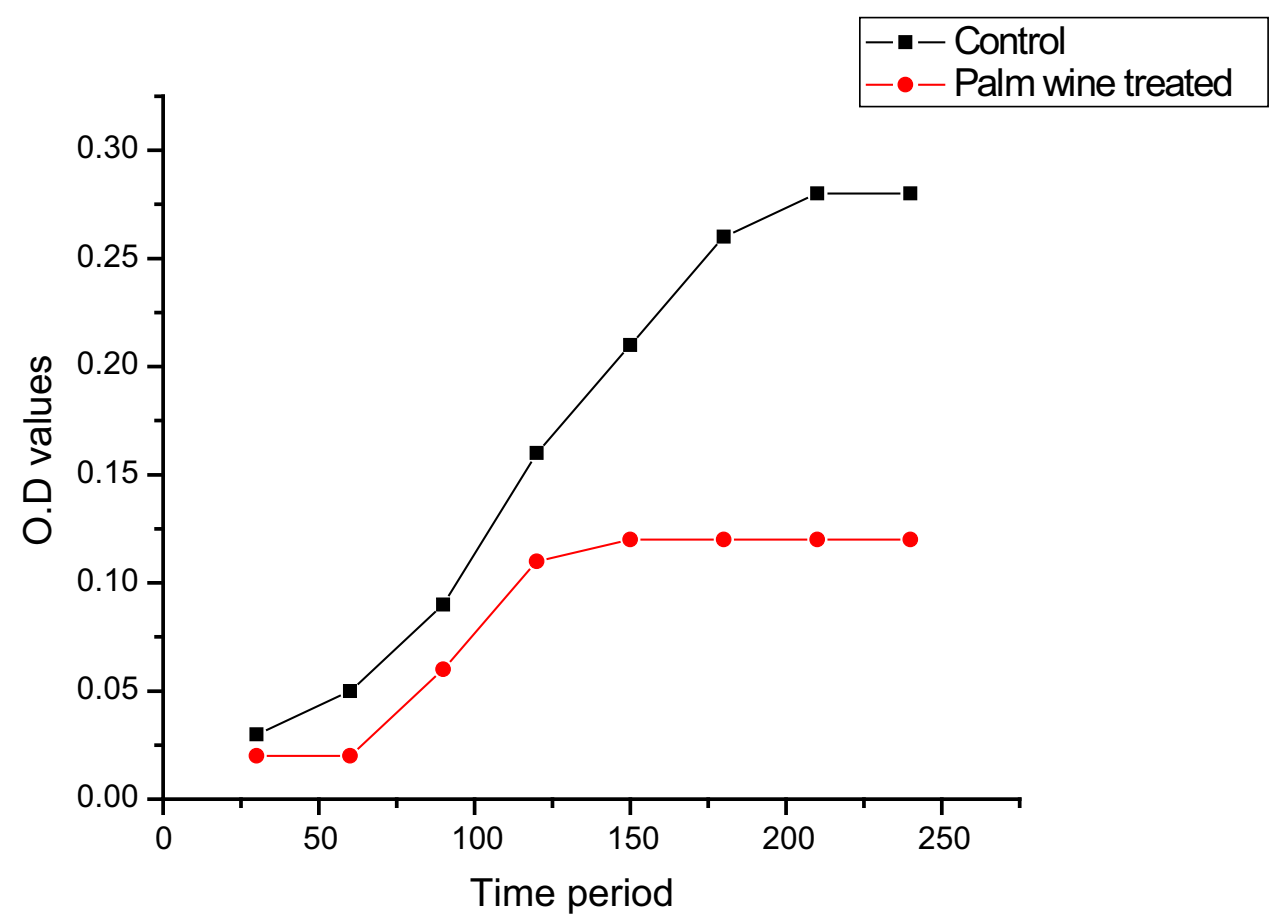

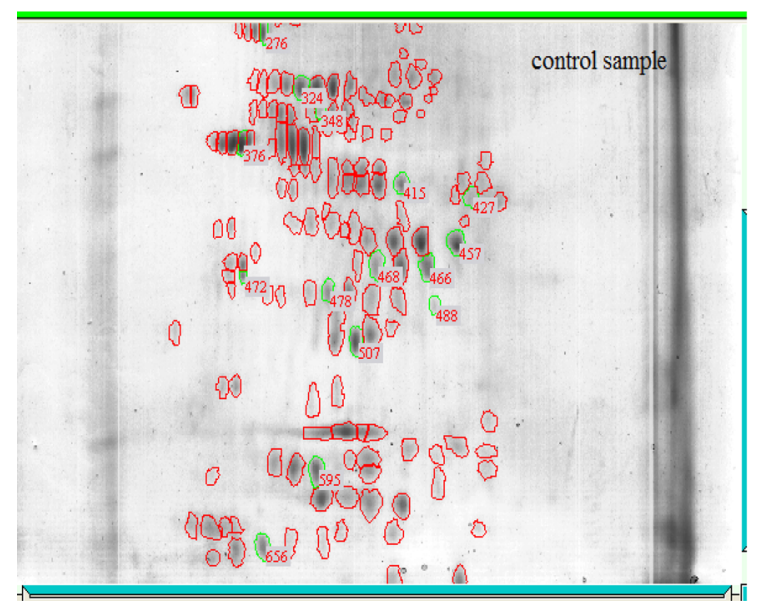

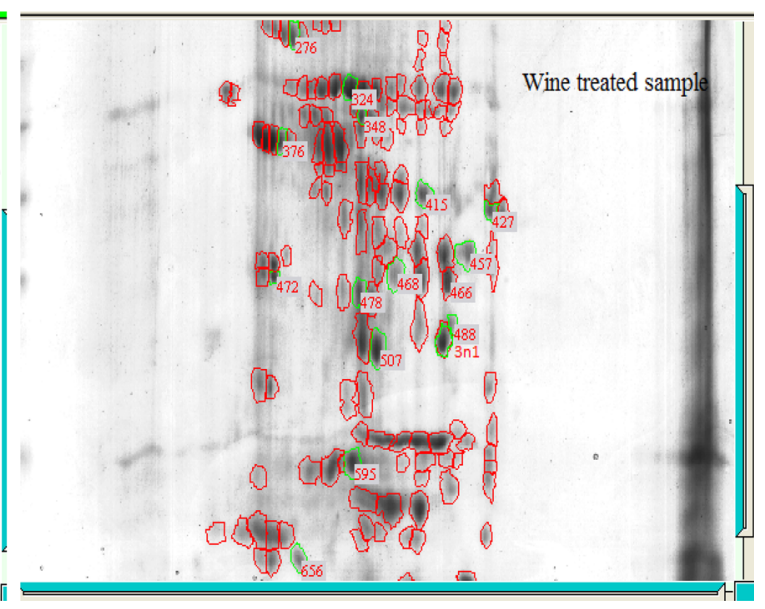

Fig. 2 2-D profile of E. coli Nissle 1917 expressed proteins under the influence of cocoti palm wine stress

\section{2-D gel analysis}

Gels were analyzed by gel scanner (Typhon Variable Mode Imager) 2-D platinum 6.0 software program (Afjehi-Sadat and Lubec 2007). It quantifies the protein spots, and showed the variation between the control and palm wine-treated gel samples; the spot size indicates upregulation and down-regulation of the protein. The expressed protein spots were separated using spot cutter, and these spots can be analyzed by MS for protein identification.

\section{MALDI-TOF MS/MS and data analysis}

Protein Spots were picked from gels, digested with trypsin, mixed with Matrix (4-hydroxy-3-methoxy cinnamic acid in acetonitrile) and allowed for MALDI-TOF MS/MS analysis (Model Voyager-DE STR, Applied Bio-systems, Foster, CA, USA). MALDI-TOF MS/MS spectra results were converted into Mascot Generic Format (MGF). Mascot is the search engine for MS spectra data (http://www. matrixscience.com). The search parameters are: peptide tolerance range is $100-1200 \mathrm{ppm}$, MS/MS tolerance range 
in between 0.2 and 2 Daltons and missed cleavage of trypsin always one, search against the NCBInr database among $E$. coli species. Proteins were distinguished based on the maximum hits, molecular weight and ion score and threshold significance $<0.05$. Phyrol 2 software was used for homology modeling (Tang et al. 2013; Vranakis et al. 2012), RASMOL for pdb file analysis, PSVS server to visualize dihedral angles $\varphi$ against $\psi$ of amino acid residues in protein structure. It shows the possible conformations of $\varphi$ and $\psi$ angles for a polypeptide. ProtParam server was used to characterize the protein physico-chemical properties and Mega-6 for phylogenetic analysis ((Rodrigo et al. 2014; Chandrasekhar et al. 2014; Vranakis et al. 2012; Tamura et al. 2013).

Table 2 E. coli Nissle 1917 expressed protein up- and down-regulation values with reference to cocoti palm wine

\begin{tabular}{llll}
\hline Spot number & Control & Wine treated & Regulation \\
\hline Up-regulation & & & \\
478 & 0.618591 & 0.911168 & 1.472973257 \\
415 & 0.75465 & 1.09259 & 1.447810243 \\
324 & 1.1867 & 1.39784 & 1.177921968 \\
507 & 1.46744 & 1.60907 & 1.096515019 \\
466 & 0.946688 & 0.950442 & 1.003965404 \\
Down-regulation & & & \\
276 & 0.822424 & 0.824411 & 0.997589794 \\
376 & 1.45419 & 0.616171 & 2.36004291 \\
\hline
\end{tabular}

\section{Results and discussion}

In the present study, we have analyzed E. coli Nissle 1917 differentially expressed proteins with the influence of cocoti palm wine. Palm wine-treated E. coli showed less growth compared to controls. Trizol protein extraction method was used to isolate the protein sample for 2-D analysis. Totally, we isolated eight differentially expressed proteins and out of these eight proteins, five proteins showed up-regulation, two proteins showed down-regulation the remaining one is a newly expressed protein (Fig. 2) which are not found in control samples; protein expression levels were analyzed using an image analyzer and the regulation values are presented in Table 2 and Fig. 3 (Natale et al. 2011). The expressed proteins were analyzed by MALDI-TOF/MS and the results are represented in Fig. 4. Protein name as well as sequence coverage and calculated pI were obtained using the MASCOT search engine (http://www.matrixscience.com) (Tang et al. 2013; Sarkisova et al. 2014); the results are summarized in Table 3. Physico-chemical characters like molecular weight, instability index, aliphatic index, extinction coefficient, total number of atoms, protein molecular formula and GRAVY(grand average of hydropathy) were analyzed by ProtParam server (http://web.expasy.org/protparam/) (Vranakis et al. 2012; Tamura et al. 2013) and the results are shown in Table 4. Target sequence was aligned with templates using SWISSMODEL server (http://swissmodel. expasy.org/) and the results are represented in Fig. 5. Homology structures of expressed proteins under cocoti wine stress were visualized by phyre- 2 database and the
Fig. 3 E. coli Nissle 1917 cocoti palm wine stress expressed protein up- and down-regulation graph images
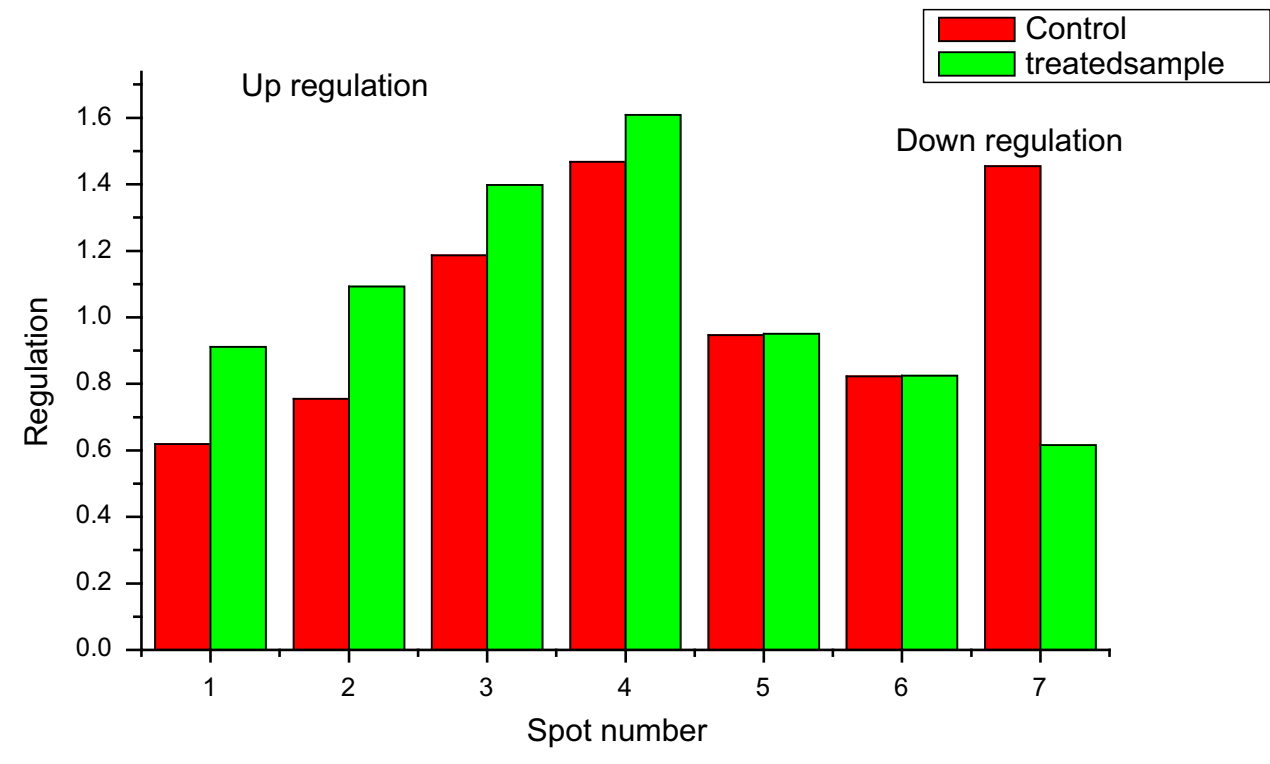
$\underline{\text { Spot.no-478 }}$

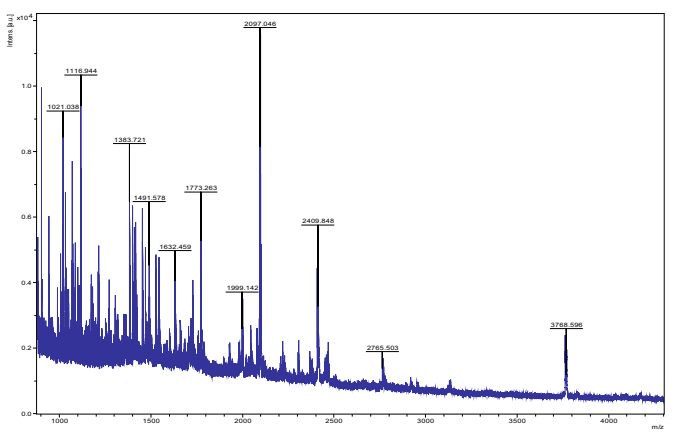

$\underline{\text { Spot.no-324 }}$

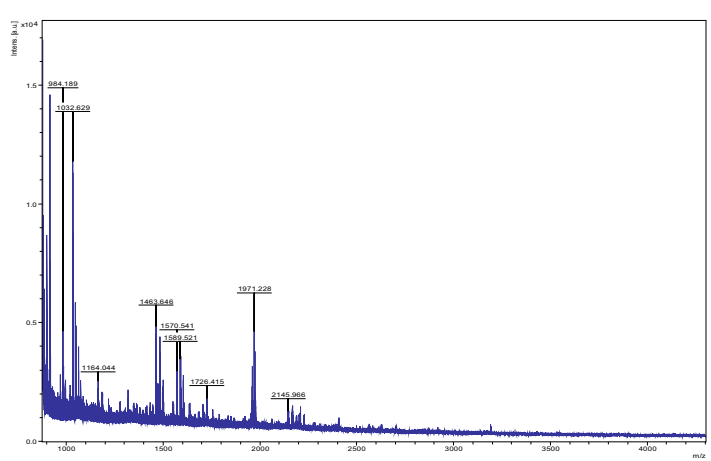

$\underline{\text { Spot.no-466 }}$

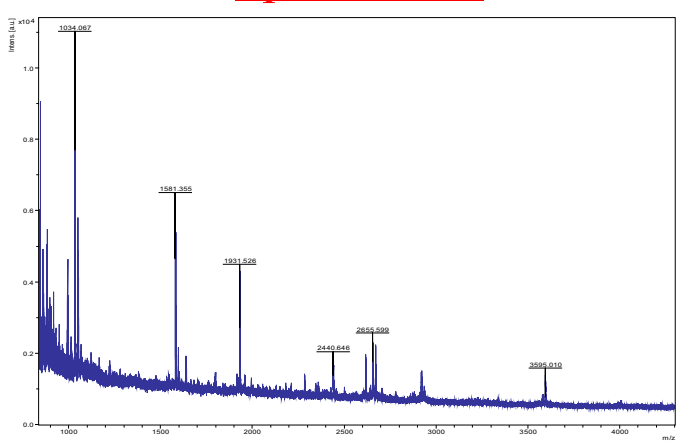

Spot.no-276

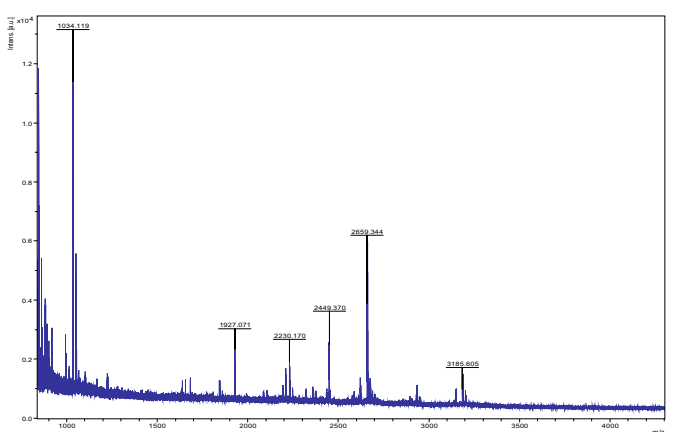

$\underline{\text { Spot.no-415 }}$

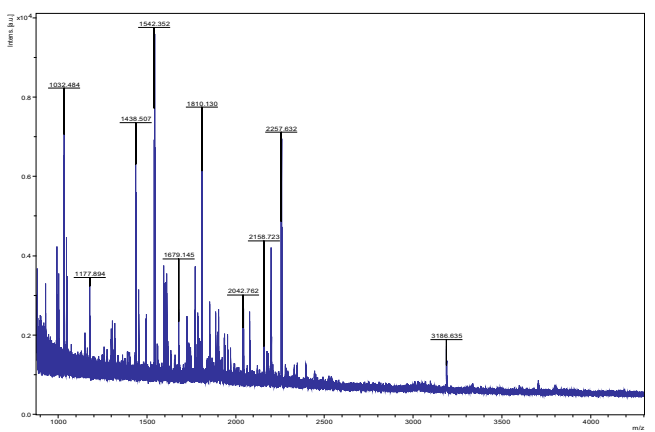

Spot.no-507

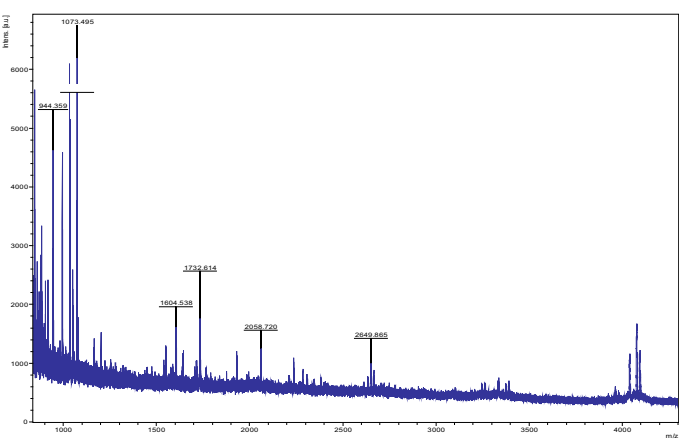

Spot.no-3n1

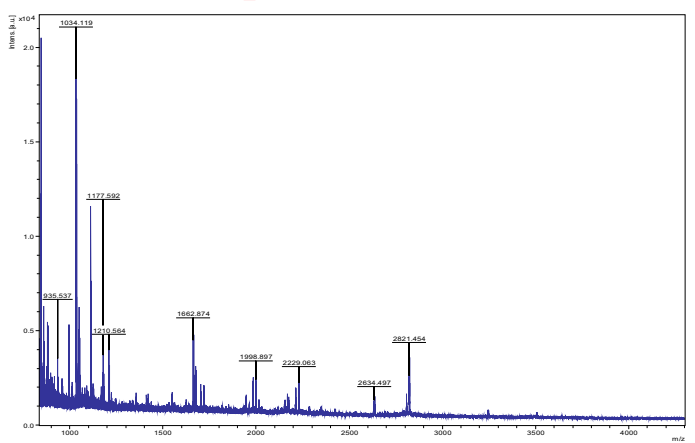

Spot.no-376

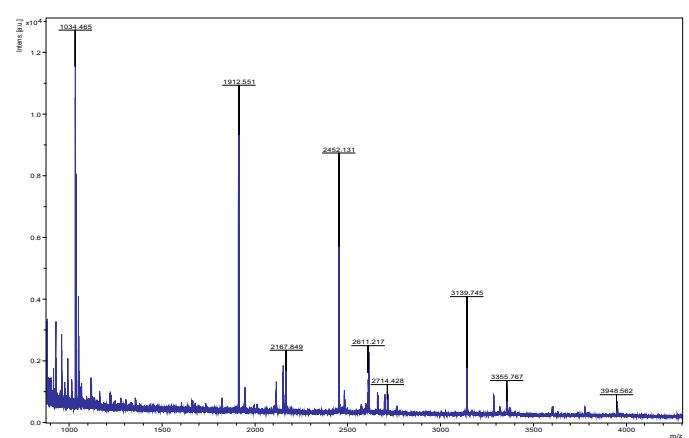

Fig. 4 MALDI-TOF-MS analysis of expressed proteins in response to cocoti palm wine stress 
Table 3 List of newly expressed proteins of E. coli Nissle 1917 under cocoti wine stress identified by MASCOT search

\begin{tabular}{|c|c|c|c|c|c|c|}
\hline $\begin{array}{l}\text { Spot } \\
\text { number }\end{array}$ & Protein name & $\begin{array}{l}\text { No. of amino } \\
\text { acids }\end{array}$ & $\begin{array}{l}\text { Protein } \\
\text { score }\end{array}$ & $\begin{array}{l}\text { Molecular } \\
\text { weight }\end{array}$ & $\begin{array}{l}\text { Sequence } \\
\text { coverage }\end{array}$ & $\begin{array}{l}\text { Calculated } \\
\text { PI }\end{array}$ \\
\hline 478 & $\begin{array}{l}\text { Small toxic polypeptide } \\
\text { LDRA_ECOLI }\end{array}$ & 35 & 25 & 4013.8 & 94 & 10.83 \\
\hline 415 & 30S ribosomal protein RS11_ECO24 & 177 & 34 & $18,903.7$ & 25 & 9.71 \\
\hline 324 & $\begin{array}{l}\text { Transcription anti-termination protein RFAH- ECO57 } \\
\text { NusA }\end{array}$ & 162 & 35 & $18,340.2$ & 17 & 8.55 \\
\hline 507 & $\begin{array}{l}\text { PUR7-eco24- phosphoribosylamidazole- } \\
\text { succinocarboxamide synthase }\end{array}$ & 237 & 32 & 26,955 & 16 & 5.05 \\
\hline 466 & $\begin{array}{l}\text { Xanthine dehydrogenase iron sulfur binding } \\
\text { subunit XDHC_Eco57 }\end{array}$ & 159 & 32 & $16,949.7$ & 25 & 6.79 \\
\hline $3 n 1$ & $\begin{array}{l}\text { P21 prophage-derived head-stabilizing } \\
\text { proteinVG03_ECOL6 }\end{array}$ & 68 & 37 & 7620.8 & 41 & 10.70 \\
\hline 276 & $\begin{array}{l}\text { UPF0033 protein } \\
\text { YEDF_ }\end{array}$ & 77 & 38 & 8638.9 & 53 & 4.83 \\
\hline 376 & $\begin{array}{l}\text { Probable adenosine monophosphate-protein transferase } \\
\text { FIC_ECOLI }\end{array}$ & 200 & 29 & 22,960 & 23 & 5.16 \\
\hline
\end{tabular}

Table 4 ProtParam analysis of E. coli Nissle 1917 expressed proteins under cocoti wine stress

\begin{tabular}{|c|c|c|c|c|c|c|c|c|}
\hline $\begin{array}{l}\text { Spot } \\
\text { no. }\end{array}$ & Formula & $\begin{array}{l}\text { Total no. of } \\
\text { atoms }\end{array}$ & $\begin{array}{l}\text { Extinction } \\
\text { coefficient }\end{array}$ & $\begin{array}{l}\text { Molecular weight } \\
\text { (Daltons) }\end{array}$ & $\begin{array}{l}\text { Estimated half- } \\
\text { life }(h)\end{array}$ & $\begin{array}{l}\text { Instability } \\
\text { index }\end{array}$ & $\begin{array}{l}\text { Aliphatic } \\
\text { index }\end{array}$ & GRAVY \\
\hline 478 & $\mathrm{C}_{190} \mathrm{H}_{291} \mathrm{~N}_{49} \mathrm{O}_{43} \mathrm{~S}$ & 575 & 16,500 & 4013.8 & $>10$ & 23.18 & 117.43 & 0.760 \\
\hline 415 & $\mathrm{C}_{837} \mathrm{H}_{1374} \mathrm{~N}_{244} \mathrm{O}_{247} \mathrm{~S}_{3}$ & 2705 & 12,950 & $18,903.7$ & $>10$ & 19.48 & 91.41 & -0.227 \\
\hline 324 & $\mathrm{C}_{833} \mathrm{H}_{1313} \mathrm{~N}_{223} \mathrm{O}_{233} \mathrm{~S}$ & 2607 & 13,075 & $18,340.2$ & $>10$ & 35.21 & 93.27 & -0.141 \\
\hline 507 & $\mathrm{C}_{1200} \mathrm{H}_{1908} \mathrm{~N}_{320} \mathrm{O}_{362} \mathrm{~S}_{1}$ & 3802 & 21,555 & 26,995 & $>10$ & 37.62 & 88.02 & -0.370 \\
\hline 466 & $\mathrm{C}_{730} \mathrm{H}_{1202} \mathrm{~N}_{204} \mathrm{O}_{225} \mathrm{~S}_{16}$ & 2377 & 10,595 & $16,949.7$ & $>10$ & 42.33 & 88.99 & 0.072 \\
\hline $3 n 1$ & $\mathrm{C}_{324} \mathrm{H}_{564} \mathrm{~N}_{108} \mathrm{O}_{99} \mathrm{~S}$ & 1097 & 1490 & 7620.8 & $>10$ & 56.26 & 108.97 & -0.291 \\
\hline 276 & $\mathrm{C}_{382} \mathrm{H}_{615} \mathrm{~N}_{101} \mathrm{O}_{116} \mathrm{~S}$ & 1219 & 6085 & 8638.9 & $>10$ & 47.99 & 98.70 & -0.27 \\
\hline 376 & $\mathrm{C}_{1028} \mathrm{H}_{1578} \mathrm{~N}_{282} \mathrm{O}_{301} \mathrm{~S}$ & 3197 & 31,525 & 22,960 & $>10$ & 43.13 & 86.90 & -0.360 \\
\hline
\end{tabular}

results are summarized in Fig. 6. The results of the RasMol server, to analyze the protein homology, total number of H-bonds, helices, strands, turns, atoms, groups and number of bonds were presented in Table 5; validation of the expressed protein was analyzed by protein structure validation software suite (PSVS) (http://psvs-1_5-dev.nesg.org) and the results are presented in Fig. 7. Phylogenetic analysis explains the relationship of the protein presented in Fig. 8; UniProt search (http://www. uniprot.org/) helped to find the protein functional information (Alpi et al. 2015).

In the present study, we have analyzed E. coli Nissle 1917 differentially expressed proteins with the influence of cocoti palm wine. The probiotic E. coli Nissle 1917 treated with cocoti palm wine sample (as per MIC) showed a total of eight differentially expressed proteins which were separated from 2-D gels based on protein expression level. Overall, five proteins showed up-regulation compared to control and these protein spots were indicated by the numbers 478, 415, 324, 507, 466. Two proteins showed down-regulation and these protein spots were indicated by the numbers of 276,376 . Only one newly expressed protein identified in wine-treated gel in the spot was indicated as $3 n 1$. These spots were digested with trypsin and then allowed for MALDI-TOF analysis. The up-regulated proteins involved in cell signaling process, protein binding, anti-termination and termination process, electron transport mechanism and catalytic activities; the down-regulated 
Spot number

478

324

507

466

$3 n 1$

276

376
Sequence Alignment

Tatget 1 MTLAQFAMIFWHDLAAPILAGIITAIVS WWRMR 95

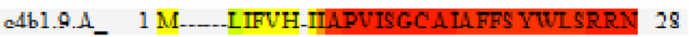

Fig. 5 Sequence alignment of E. coli Nissle 1917 expressed proteins with response to cocoti palm wine

proteins involved in cellular response to DNA damage stimulus and regulatory mechanisms; and the newly expressed protein involved in viral life cycle activities (Artzi et al. 2015).

Physico-chemical properties of the expressed proteins which were analyzed by ProtParam server revealed that the coefficient value range of the expressed proteins is 1490-31,525 Daltons. The half-life time indicates that half of the amount of protein disappears in a cell after its synthesis and all the expressed proteins have showed $>10 \mathrm{~h}$ as the half-life period. Instability index explains the nature of the proteins, based on these three proteins were stable and the remaining expressed proteins were unstable. Aliphatic index explains coverage of aliphatic amino acids in the present proteins; it supports the thermal stability of globular proteins. The range of an aliphatic index of the 


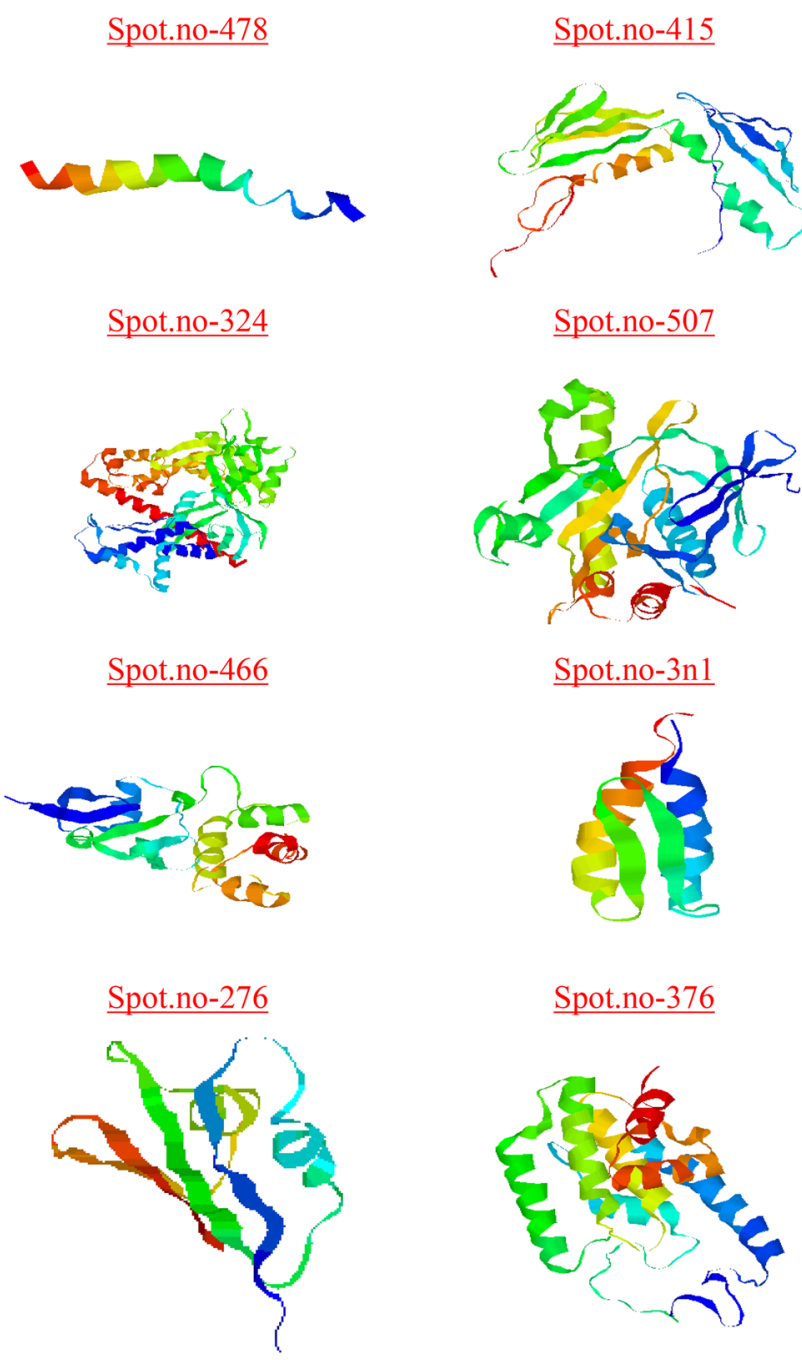

Fig. 6 Homology modeling of E. coli Nissle 1917 expressed proteins with response to cocoti wine

expressed proteins is $86.90-117.43$. The grand average of hydropathicity (GRAVY) index of the proteins ranged from -0.360 to 0.760 . Molecular formula of proteins is also explained and all the results are summarized in Table 4 (Lai et al. 2003).

The target sequence was searched by Swiss model against PDB for selection of template protein. A total of eight expressed proteins was aligned in suitable templates, which were found based on the sequence superimposition up-regulated proteins aligned with C4B1, 3J5E, 4MTN, 2Z02, 1ZXI and the down-regulated proteins aligned with $1 \mathrm{JE} 3,3 \mathrm{ZC} 7$. These two templates and the newly expressed protein aligned with the 1HYW template as shown in Fig. 5 (Lima et al. 2009). To predict homology modeling using Phyre-2 server and to analyze these structures, we used RASMOL version 2.6 (Sheehan and Sullivan 2011) and the results are represented in Fig. 6 and Table 5. Validation of the expressed protein models was done with Protein structure validation server (PSVS). The $\psi$ and $\varphi$ distributions of the Ramachandran's plots of non-glycine, non-proline residues are summarized in Fig. 7. Phylogenetic analysis explains the evolutionary relationship between the expressed protein sequences the results are shown in Fig. 8 (Brewer et al. 2014).

\section{Conclusion}

2D Page coupled with MALDI-TOF-MS for protein identification allowed us to explore the protein complex of probiotic E. coli under cocoti palm wine stress. Based on comparative proteomic analysis we identified five up-regulated, two down-regulated proteins and also noticed one newly expressed protein (3N1). Complete analysis explains that the up-regulated proteins involved in cell signaling, termination and anti-termination process suppress the host pathogens, electron transport mechanism, and catalytic activities; down-regulated proteins involved in cellular responses to DNA damage stimulus and regulation mechanisms and also helps to bind the mutated gene. Newly

Table 5 Structural analysis of homology models by RasMol

\begin{tabular}{|c|c|c|c|c|c|c|c|}
\hline Spot number & No. of groups & No. of atoms & No. of bonds & No. of H-bonds, & No. of helices & No. of strands & No. of turns \\
\hline 478 & 28 & 230 & 241 & 23 & 3 & 0 & 1 \\
\hline 415 & 175 & 1313 & 1339 & 89 & 3 & 14 & 20 \\
\hline 324 & 404 & 3153 & 3211 & 305 & 19 & 18 & 29 \\
\hline 507 & 237 & 1894 & 1924 & 172 & 9 & 22 & 21 \\
\hline 466 & 156 & 1148 & 1175 & 98 & 10 & 7 & 21 \\
\hline $3 n 1$ & 58 & 448 & 452 & 41 & 2 & 2 & 4 \\
\hline 276 & 77 & 765 & 776 & 48 & 2 & 6 & 7 \\
\hline 376 & 186 & 1515 & 1557 & 129 & 9 & 4 & 17 \\
\hline
\end{tabular}




\section{Spot No- 478}

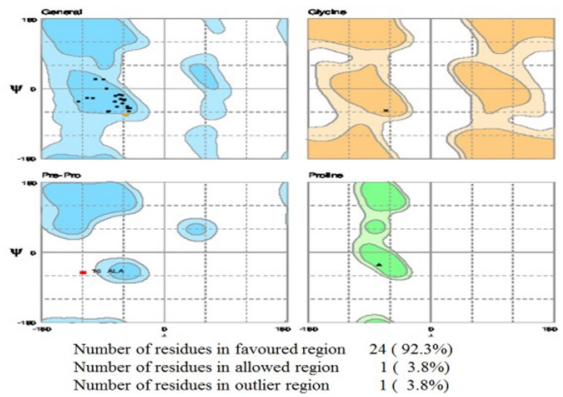

Spot No- 324

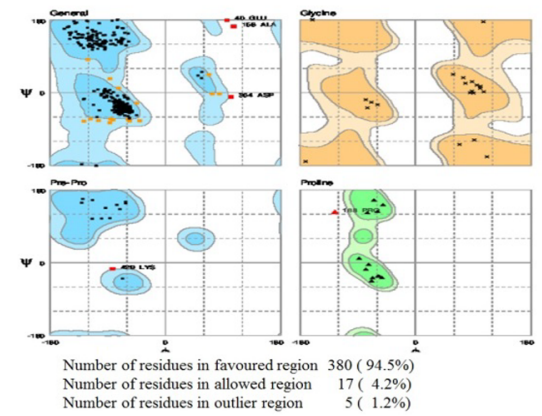

Spot No-466

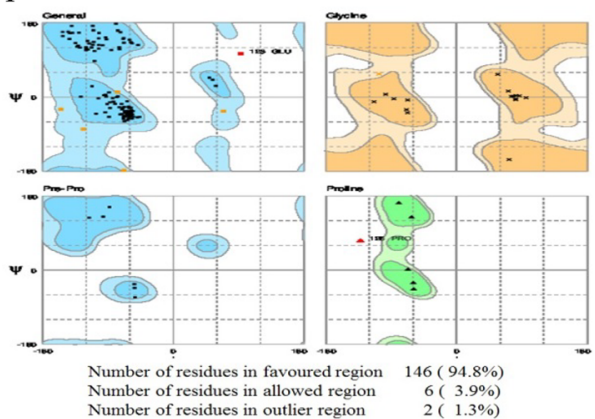

Spot No-276

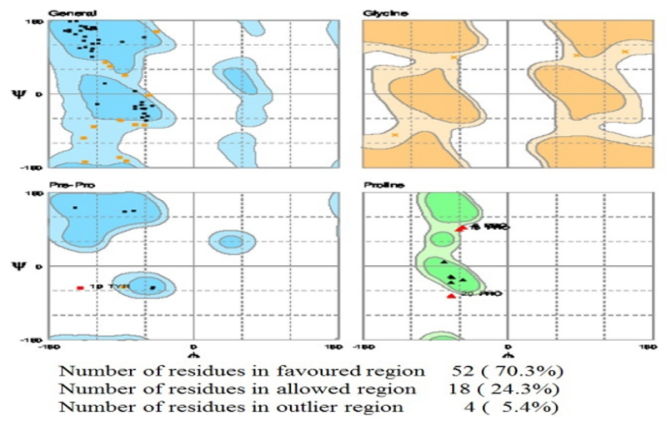

Spot No- 415

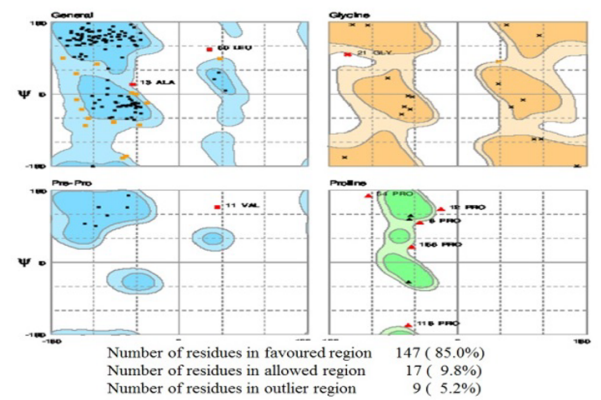

Spot No- 507

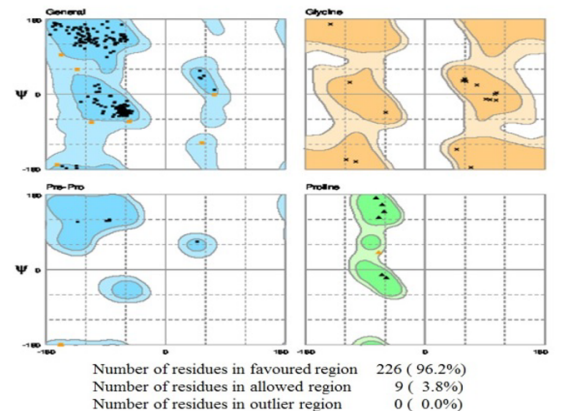

Spot No- 3n1

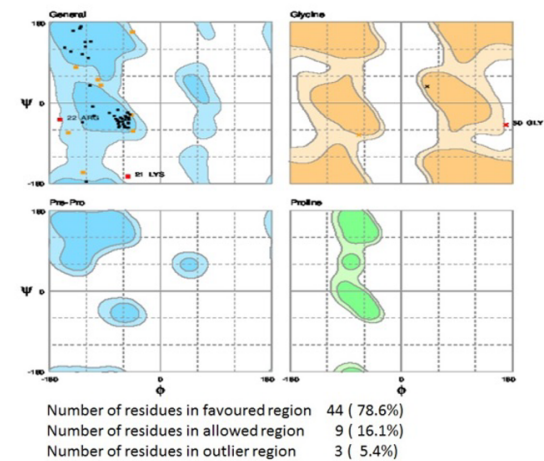

Spot No-376

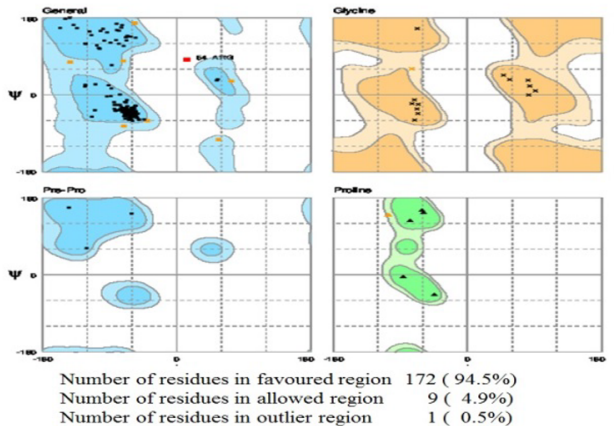

Fig. 7 Ramachandran's plot analysis of expressed E. coli Nissle 1917 proteins under cocoti palm wine stress 


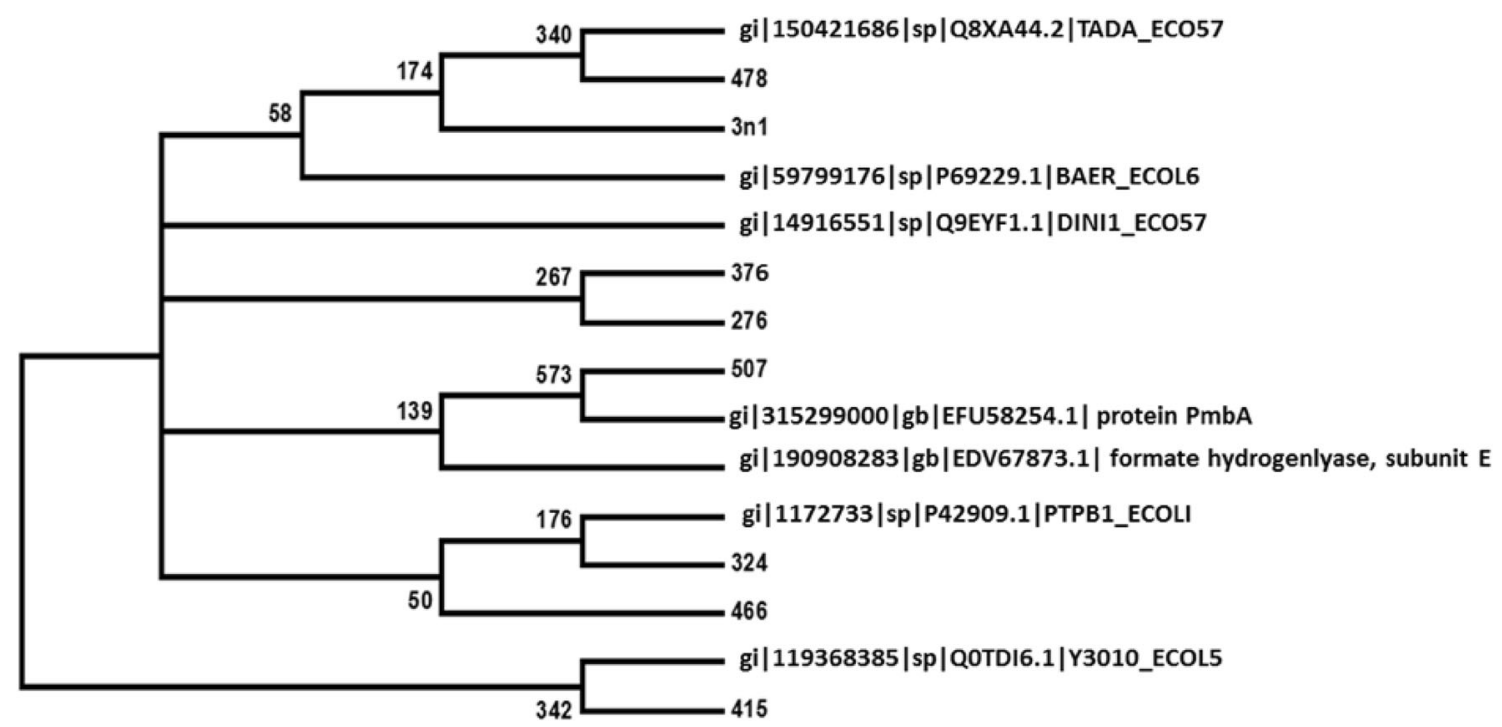

Fig. 8 Phylogenetic relationship of expressed proteins based on the Mascot search results

regulated protein $(3 \mathrm{~N} 1)$ involves in viral life cycle activities. These results suggested that the cocoti palm wine stress effects on probiotic E. coli Nissle 1917.

\section{Compliance with ethical standards}

Conflict of interest The authors declare that they have no conflict of interest in the publication.

\section{References}

Afjehi-Sadat L, Lubec G (2007) Identification of enzymes and activity from two- dimensional gel electrophoresis. Nat Protoc 2:2318-2324

Agrawal GK, Yonekura M, Iwahashi Y, Iwahashi H, Rakwal R (2005) System, trends and perspectives of proteomics in dicot plants. Part III: unraveling the proteomes influenced by the environment, and at the levels of function and genetic relationships. J Chromatogr B Anal Technol Biomed Life Sci 815:137-145

Alpi E, Griss J, da Silva AW, Bely B, Antunes R, Zellner H, Rios D, Donovan CO, Vizcaino JA, Martin MJ (2015) Analysis of the tryptic search space in UniProt databases. Proteomics 15:48-57

Artzi L, Morag E, Barak Y, Lamed R, Bayera EA (2015) Clostridium clariflavum: key cellulosome players are revealed by proteomic analysis. MBio 6:e0411-e0415

Brewer TE, Stroupe ME, Jones KM (2014) The genome, proteome and Phylogenetic analysis of Sinorhizobium meliloti phage $\Phi \mathrm{M} 12$, the founder of a new group of T4-superfamilyphages. Virology 450-451:84-97

Chandrasekhar K, Sreedevi B, Sreevani S, Dileep A, Lebonah DE, Seshapani P, Pramoda kumara J (2014) Characterisation and structural dynamics of differentially expressed proteins of probiotic Escherichia coli Nissle 1917 in response to Cocos nucifera Sap. J Proteom Bio 7:179-185

Dworzanski JP, Deshpande SV, Chen R, Jabbour R, Snyder AP, Wick $\mathrm{CH}, \mathrm{Li}$ L (2006) Mass spectrometry-based proteomics combined with bioinformatic tools for bacterial classification. J Proteome Res 5:76-87
Eluwa M, Ekere E, Ekanem T, Akpantah A, Igiri A (2008) Teratogenic effect of beer and palm wine on the histology of the fetal kidney of Wistar rats. Internet J Toxicol 6:1-5

Foxx-Orenstein AE, Chey WD (2012) Manipulation of the gut microbiota as a novel treatment strategy for gastrointestinal disorders. Am J Gastroenterol Suppl 1:41-46

Gabbard LS, Lacy BE, Levine GM, Crowell MD (2014) The impact of alcohol consumption and cholecystectomy on small intestinal bacterial overgrowth. Dig Dis Sci 59:638-644

Grozdanov L, Raasch C, Schulze J, Sonnenborn U, Gottschalk G, Hacker J, Dobrindt U (2004) Analysis of the genome structure of the nonpathogenic probiotic Escherichia coli strain Nissle 1917. J Bacteriol 186:5432-5544

Henker J, Laass M, Blokhin BM, Bolbot YK, Maydannik VG, Elze M, Wolff C, Schulze J (2007) The probiotic Escherichia coli strain Nissle $1917(\mathrm{EcN})$ stops acute diarrhoea in infants and toddlers. Eur J Pediatr 166:311-318

John MW (2005) The proteomics protocols handbook. Humana, New Jersey

Krishnamurthy T, Rajamani U, Ross PL, Jabbour R, Nair H, Eng J, Yates J, Douglas MTD, Stahl C, Lee TD (2000) Mass spectral investigation of microorganisms. $\mathrm{J}$ Toxicol Toxin Rev 19:95-117

Lai EM, Phadke ND, Kachman MT, Giorno R, Vazquez S, Vazquez JA, Maddock JR, Driks A (2003) Proteomic analysis of the spore coats of Bacillus subtilis and Bacillus anthracis. J Bacteriol 185:1443-1454

Lima T, Auchincloss AH, Coudert E, Keller G, Michoud K, Rivoire C, Bulliard V (2009) HAMAP: a database of completely sequenced microbial proteome sets and manually curated microbial protein families in UniProtKB/Swiss-Prot. Nucleic Acids Res 37:D471-D478

Natale M, Maresca B, Abrescia P, Bucci EM (2011) Image analysis workflow for 2-D electrophoresis gels based on Image. J Proteom Insights 4:37-49

Nissle A (1918) Die antagonistische Behandlung chronischer Darmstörungen mit Colibakterien. Med Klin 2:29-33

Nystrom T (2004) Stationary-phase physiology. Annu Rev Microbiol 58:161-181

Panga JR, Aishwarya AR, Darpan M, Samridhi S, Ravinder K, Rekha J, Kishore G, Namita P, Srikanth R, Sanjeeva S (2013) A Simple 
protein extraction method for proteomic analysis of diverse biological specimens. Curr Proteom 10:298-311

Rabilloud T, Lelong C (2011) Two-dimensional gel electrophoresis in proteomics: a tutorial. J Proteom 74:1829-1841

Ringel Y, Quigley EMM, Li HC (2012) Using probiotics in gastrointestinal disorders. Am J Gastroenterol Suppl 1:34-40

Rodrigo MA, Ondrej Z, Krizkova S, Moulick A, Adam V, Kizek R (2014) MALDI-TOF MS as evolving cancer diagnostic tool: a review. J Pharm Biomed Anal 95:245-255

Sarkisova SA, Lotlikar SR, Guragain M, Kubat R, Cloud J, Franklin JM, Patrauchan MA (2014) A Pseudomonas aeruginosa EFHand protein, EfhP (PA4107), modulates stress responses and virulence at high calcium concentration. PLoS One. doi:10.1371/ e0098985

Schmidt A, Forne I, Imhof A (2014) Bio-informatic analysis of proteomics data. BMC Syst Biol 8:S2-S3
Sheehan D, Sullivan SO (2011) Online homology modelling as a means of bridging the sequence-structure gap. Bioeng Bugs 2:299-305

Soares NC, Spat P, Krug K, Macek B (2013) Global dynamics of the Escherichia coli proteome and phosphor proteome during growth in minimal medium. J Proteom Res 12:2611-2621

Tamura K, Stecher G, Peterson D, Filipski A, Kumar S (2013) MEGA6: molecular evolutionary genetics analysis version 6.0. Mol Biol Evol 30:2725-2729

Tang Y, Underwood A, Gielbert A, Woodward MJ, Petrovskaa L (2013) Meta proteomics analysis reveals the adaptation process for the chicken gut Microbiota. Appl Env Microbiol 80:478-485

Vranakis I, De Bock PJ, Papadioti A, Tselentis Y, Gevaert K, Georgios T, Psaroulaki A (2012) Quantitative proteome profiling of $C$. burnetii under Tetracycline stress conditions. PLoS One. doi:10.1371/e0033599 